\title{
A multiplex realtime PCR assay enables simultaneous rapid detection and quantification of bacteria associated with acute oak decline
}

Crampton, Bridget G.; Plummer, Sarah; Kaczmarek, Marciej; McDonald, James; Denman, Sandra

\section{Plant Pathology}

DOI:

10.1111/ppa.13203

Published: 01/09/2020

Peer reviewed version

Cyswllt i'r cyhoeddiad / Link to publication

Dyfyniad o'r fersiwn a gyhoeddwyd / Citation for published version (APA):

Crampton, B. G., Plummer, S., Kaczmarek, M., McDonald, J., \& Denman, S. (2020). A multiplex realtime PCR assay enables simultaneous rapid detection and quantification of bacteria associated with acute oak decline. Plant Pathology, 69(7), 1301-1310.

https://doi.org/10.1111/ppa.13203

\footnotetext{
Hawliau Cyffredinol / General rights

Copyright and moral rights for the publications made accessible in the public portal are retained by the authors and/or other copyright owners and it is a condition of accessing publications that users recognise and abide by the legal requirements associated with these rights.

- Users may download and print one copy of any publication from the public portal for the purpose of private study or research.

- You may not further distribute the material or use it for any profit-making activity or commercial gain

- You may freely distribute the URL identifying the publication in the public portal?
}

Take down policy

If you believe that this document breaches copyright please contact us providing details, and we will remove access to the work immediately and investigate your claim. 


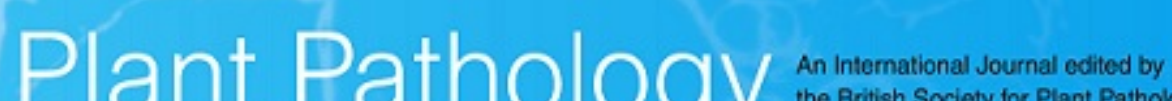

\section{A multiplex real-time PCR assay enables simultaneous rapid detection and quantification of bacteria associated with Acute Oak Decline}

\begin{tabular}{|r|l|}
\hline Journal: & Plant Pathology \\
\hline Manuscript ID & PP-19-499.R1 \\
\hline Manuscript Type: & Original Article \\
\hline Author: & O5-Apr-2020 \\
\hline Complete List of Authors: & $\begin{array}{l}\text { Crampton, Bridget; Forest Research; Bangor University, School of } \\
\text { Natural Sciences } \\
\text { Plummer, Sarah; Forest Research, Centre for Ecosystems, Society and } \\
\text { Biosecurity, Forest Research; RHS Wisley } \\
\text { Kaczmarek, Maciej; Forest Research, Centre for Ecosystems, Society and } \\
\text { Biosecurity; Edinburgh Napier University, School of Applied Sciences } \\
\text { McDonald, James; Bangor University, School of Natural Sciences } \\
\text { Denman, Sandra; Forest Research, Centre for Ecosystems, Society and } \\
\text { Biosecurity }\end{array}$ \\
\hline Topics: & diagnostics \\
\hline Organisms: & bacteria \\
\hline Other Keywords: & acute oak decline, TaqMan \\
\hline
\end{tabular}

\section{SCHOLARONE Manuscripts}


Running head: CRAMPTON et al.

\section{A multiplex real-time PCR assay enables simultaneous rapid detection and quantification of bacteria associated with acute oak decline}

B. G. Crampton ${ }^{1,2}$, S. J. Plummer ${ }^{1}$, M. Kaczmarek¹, J. E. McDonald², S. Denman ${ }^{1}$

${ }^{1}$ Centre for Ecosystems, Society and Biosecurity, Forest Research, Alice Holt Lodge, Farnham, Surrey, GU10 4LH, UK

${ }^{2}$ School of Natural Sciences, Bangor University, Bangor, Gwynedd, LL57 2UW, UK

Corresponding author

B. G. Crampton, e-mail: Bridget.Crampton@ForestResearch.gov.uk

Current addresses

S. J. Plummer: RHS Wisley, Wisley Lane, Woking, GU23 6QB, UK

M. Kaczmarek: School of Applied Sciences, Edinburgh Napier University, Edinburgh, EH11 4BN, UK

Acute oak decline (AOD) is a syndrome affecting mature oak trees and is characterized by stem bleeds from vertical fissures on trunks, and inner bark necrosis caused by a polybacterial consortium, in which Gibbsiella quercinecans and Brenneria goodwinii, and to 
a lesser extent Rahnella victoriana and Lonsdalea britannica, play key roles. Here we report a novel multiplex real-time PCR assay that enables simultaneous and rapid detection and quantification of these four bacterial species from stem bleed swabs. Experiments with axenic cultures were performed to determine specificity and sensitivity of the multiplex quantitative PCR (qPCR). Whilst the primer/probe set for B. goodwinii was species-specific, primer/probe sets for the other three species were able to identify other members of their respective genera. There was no cross detection of genera within the multiplex qPCR, and non-target bacteria were not detected. The multiplex AOD assay had differential sensitivity for each bacterial species. The assay was evaluated on swab samples collected from stem bleeds of declining oak trees at a site in south-east England and was able to detect all four bacterial species. Absolute quantification of the bacteria from swab samples was possible through the inclusion of a standard curve prepared from dilutions of gene copy standards. This diagnostic tool will facilitate rapid detection of AOD-associated bacteria from samples that can easily be taken by non-specialists without specific training, and will also find application in other experimental work such as pathogenicity and control trials.

\section{Key words}

acute oak decline, Brenneria, Gibbsiella, Lonsdalea, multiplex real-time PCR, Rahnella

\section{Introduction}

Acute oak decline (AOD) is a recently described syndrome affecting mature oak trees in England (Denman and Webber, 2009). Quercus robur (pedunculate oak) and Q. petraea (sessile oak) are particularly susceptible to AOD, which is characterized by typical symptoms 
of stem bleeds from vertical fissures on oak trunks, irregular lesions in the inner bark beneath the bleed area, and presence of larval galleries of the buprestid Agrilus biguttatus close to the lesions (Denman et al., 2014; Brady et al., 2017; Brown et al., 2017). Oak trees are thought to be predisposed to AOD attacks through local biotic and environmental factors (Brown et al., 2016, 2018) and often die within four to five years following the onset of symptom development.

Marker gene amplicon sequencing, metagenomics, and isolation of bacteria from stem bleeds and necrotic inner bark lesions identified two key, consistently occurring, bacteria species, Gibbsiella quercinecans and Brenneria goodwinii (Denman et al., 2012, 2018; Sapp et al., 2016), which were shown to cause lesions in subsequent oak log inoculation trials (Denman et al., 2018). Causation by bacteria was further confirmed through multi-omic analysis of microbiota associated with AOD (Broberg et al., 2018). In addition, isolation and log inoculation studies implicated a secondary role for Rahnella spp. and Lonsdalea britannica (Brady et al., 2014b; Li et al., 2017) in AOD development (Denman et al., 2018; C. Brady, University of the West of England, UK, personal communication). Recent genome comparisons of AOD bacteria with other phytopathogens suggest that B. goodwinii and $L$. britannica are primary pathogens containing suites of pathogenicity and virulence genes encoding T3SS, harpins, and effectors, and that G. quercinecans and Rahnella sp. contribute to tissue necrosis through the release of plant cell wall-degrading enzymes (PCWDEs) (Doonan et al., 2019). Furthermore, a recent population study of B. goodwinii isolates from oak in the UK demonstrated that the population of this bacterium in the UK appears to be primarily clonal and may have an endemic form with high levels of recombinant evolution taking place (Kaczmarek et al., 2017), which is typical to native bacterial pathogens (Smith et al., 2000; Vinatzer et al., 2014). 
Real-time PCR applications have enabled plant pathologists to develop assays for rapid detection of pathogens without the need for their isolation from diseased plant material (Schaad and Frederick, 2002). This rapid detection enables early, swift management through containment, control, and/or eradication of pathogens before they spread. Two real-time PCR methods can be effectively applied to detect multiple plant pathogens in a sample, namely high-resolution melt (HRM) and TaqMan assays. Although HRM analysis based on the amplification product of the atpD gene has been developed for detection of G. quercinecans and B. goodwinii (Brady et al., 2016), this method currently requires the additional step of isolation of pure cultures of bacteria from diseased material on which the HRM is run, thereby adding further time and expense to the process. Furthermore, HRM is not able to quantify the number of individual bacterial species in a sample that are associated with AOD.

TaqMan assays offer the advantage of improved specificity over other real-time PCR assays through the hybridization of a species-specific probe designed to the amplification template (Schaad and Frederick, 2002). The assay exploits the 5' nuclease activity of Taq DNA polymerase together with the inclusion of template-specific fluorescent DNA probes. Amplification of the PCR product is thus directly related to the measured fluorescence (Weller et al., 2000). Detection of multiple pathogens within a sample is possible through the addition of different fluorescent dye molecules on the species-specific hybridization probes in a multiplex TaqMan assay. Whilst multiplex quantitative PCR (qPCR) applications are common in the detection of health and food related pathogens (Ibekwe et al., 2002; Liu et al., 2013), very few examples exist for the simultaneous detection of multiple plant pathogens. In 2000, Weller et al. (2000) applied a fluorogenic TaqMan PCR assay to detect Ralstonia solanacearum strains that infect potato. More recently, Enora et al. (2019) developed a tetraplex qPCR assay for simultaneous detection of Xylella fastidiosa subspecies in plant tissues. Probes for detection of the various $X$. fastidiosa subspecies were labelled with 
different fluorogenic dye and quencher molecules allowing simultaneous detection within a sample in a single PCR. Additionally, a multiplex TaqMan assay was developed by Fonseca et al. (2019) to detect three different species of Xanthomonas sp. causing necrosis and bacterial spot in Citrus cultures.

In order to better understand the origin and spread of bacterial species associated with AOD, there is a need for a reliable and rapid molecular diagnostic assay, which will enable the detection and quantification of multiple species. The apparent emerging nature of this disease (Moradi-Amirabad et al., 2019; González and Ciordia, 2020) necessitates urgent provision of a diagnostic tool. Therefore, the aim of this study was to develop a sensitive multiplex TaqMan PCR assay that is capable of simultaneous detection and quantification of four bacterial species involved in AOD syndrome in the UK, B. goodwinii, G. quercinecans, R. victoriana, and L. britannica. An important additional requirement and aim was to develop a diagnostic protocol that was nondestructive, due to the intrinsic value of mature and veteran oak trees that are affected by AOD.

\section{Materials and methods}

\subsection{Bacterial strains and growth}

All bacteria used to validate the detection assay are shown in Table 1 and Table S1. Bacteria were cultured on nutrient agar (NA; Oxoid) at $22{ }^{\circ} \mathrm{C}$ in the dark for 5 days. For real-time PCR assays, one colony of bacteria was resuspended in $100 \mu l$ phosphate-buffered saline $\mathrm{pH}$ 7.4 (PBS), vortexed and heated at $95^{\circ} \mathrm{C}$ for $10 \mathrm{~min}$. Bacterial extracts were frozen at $-20{ }^{\circ} \mathrm{C}$ until use.

\subsection{Primer and probe design}


DNA sequences of the gyrase B $(g y r B)$ gene from various Brenneria sp., Lonsdalea sp., and Rahnella sp. were downloaded from GenBank (Table S2) and sequences belonging to each genus were aligned with Geneious v. 9.0.2 (Biomatters Ltd) to identify single nucleotide polymorphisms (SNPs) between species. Primer 3 (www.Primer3.com) was applied to design primers and probes to gene regions spanning SNPs between species. A primer set and a probe were designed to a DNA-directed RNA polymerase gene (rpo) from G. quercinecans strain FRB97. This gene is directly upstream of the $r p o B$ gene used in barcoding studies (Brady et al., 2017). Primer and probe dimer formation was assessed in Primer 3 (Koressaar and Remm, 2007; Untergasser et al., 2012) to ensure there was no interaction between any of the oligonucleotides in the multiplex PCR mix. Prior to ordering the primers and probes, the reaction was tested in silico with the Multiple Primer Analyzer (www.thermofisher.com/uk/en/home/brands/thermo-scientific/molecular-biology/molecularbiology-learning-center/molecular-biology-resource-library/thermo-scientific-webtools/multiple-primer-analyzer.html).

Primers and probes binding to rpo from G. quercinecans and the gyrB gene from $B$. goodwinii, L. britannica, and R. victoriana are indicated in Table 2. All primers and probes were synthesized by Integrated DNA Technologies.

\subsection{Real-time PCR detection of AOD-associated bacteria}

Real-time PCR reactions were set up in 96-well plates, and each $10 \mu 1$ reaction contained $1 \times$ LightCycler 480 Probes Master Mix (Roche), $0.1 \mu \mathrm{M}$ Gq284F and Gq418R primers, $0.25 \mu \mathrm{M}$ each of Bg99F, Bg179R, Rv15F, Rv134R, Lb503F, Lb634R primers, $0.1 \mu \mathrm{M}$ of each probe, and $2 \mu \mathrm{l}$ bacterial sample. Each reaction was made up to $10 \mu \mathrm{l}$ with sterile distilled water. PCRs and fluorescence detections were performed on a LightCycler480 II instrument (Roche). Thermal cycling conditions included an initial denaturation step at $95^{\circ} \mathrm{C}$ for $10 \mathrm{~min}$; 
followed by 40 cycles of denaturation at $95{ }^{\circ} \mathrm{C}$ for $10 \mathrm{~s}$, annealing at $65^{\circ} \mathrm{C}$ for $30 \mathrm{~s}$, and elongation at $72{ }^{\circ} \mathrm{C}$ for $10 \mathrm{~s}$. Fluorescence at emission wavelengths of $510 \mathrm{~nm}$ (FAM), 580 $\mathrm{nm}(\mathrm{JOE}), 610 \mathrm{~nm}(\mathrm{ROX})$, and $660 \mathrm{~nm}$ (Cy5) was measured once per cycle at the end of the $65^{\circ} \mathrm{C}$ segment. The Crossing point $(\mathrm{Cp})$ values (the PCR cycle number at which the fluorescence generated through TaqMan probe cleavage exceeded the threshold; Chandelier et al., 2019) were determined by applying an absolute quantification/fit points method (Pfaffl, 2004), with the inclusion of colour compensation to account for overlap in emission spectra between fluorescent dyes.

\subsection{Preparation of DNA standards}

DNA standards for B. goodwinii (FRB171), L. britannica (FRB18), and R. victoriana (141a) gyrB and G. quercinecans (FRB97) rpo were prepared by generating amplification products with respective forward and reverse primers. Products were purified with a DNA Clean and Concentrator Kit (Zymo Research) and concentration of the purified products was measured on a Qubit 2.0 fluorimeter (Invitrogen) using a Qubit dsDNA HS Assay Kit (Invitrogen). As both the gyrB and rpo genes occur as single copies in bacteria, dilutions of the standards were made to represent $10-10^{11}$ gene copies. These copy number standards were used to quantify bacterial numbers in environmental samples with one gene copy representing one bacterium in a sample.

\subsection{Determining sensitivity of detection of TaqMan real-time PCR assays}

Single colonies of B. goodwinii (FRB171), L. britannica (FRB18), R. victoriana (141a), and G. quercinecans (FRB97T) were inoculated separately into $10 \mathrm{ml}$ Luria broth and grown for approximately $20 \mathrm{hr}$ (mid $\log$ phase) at $25^{\circ} \mathrm{C}$ with shaking on an orbital shaker (SciQuip) at $150 \mathrm{rpm}$. Optical densities ( $\mathrm{OD}_{595} \mathrm{~nm}$; LAXCO Spectrophotometer) were adjusted to 0.6, and serial dilutions of the cultures were made $\left(10^{-1}\right.$ to $\left.10^{-6}\right)$. Each dilution was plated $(2 \mu 1$ in 98 
$\mu \mathrm{l}$ PBS $)$ onto NA in triplicate and left to grow for 4 days at $22^{\circ} \mathrm{C}$. An equivalent volume $(2$ $\mu 1)$ of each dilution was subjected to the TaqMan multiplex PCR assay for AOD-associated bacteria to determine the minimum number of detectable bacteria.

\subsection{Field sample analysis}

Sterile swabs (Sterilin) were used to collect exudate from stem bleeds of four Quercus robur trees (two swabs per tree) displaying decline symptoms at a field site in south-east England in the UK $\left(51^{\circ} 40^{\prime} 37^{\prime \prime} \mathrm{N}, 00^{\circ} 16^{\prime} 49^{\prime \prime} \mathrm{W}\right)$. The sterile cotton tip of the swab was either dipped directly into the fluid seeping from the tree, or placed in a bark crack so that the cotton tip made contact with the decaying tissue. The swab was then placed back in the tube and taken back to the laboratory where it was stored at $4{ }^{\circ} \mathrm{C}$ until processing. Swabs were thoroughly rinsed in $1 \mathrm{ml}$ sterile PBS to remove bacteria, after which the PBS containing bacteria cells was then taken up into a $1 \mathrm{ml}$ syringe and filtered with constant pressure through a $5 \mu \mathrm{m}$ pore hydrophilic filter (Sartorius) into a clean $1.5 \mathrm{ml}$ microfuge tube. Filtered bacterial suspensions were centrifuged (Eppendorf 5804R) at 9,000 $\times \mathrm{g}$ for $4 \mathrm{~min}$, and subsequently the supernatant was discarded without dislodging the bacterial pellet. Bacterial pellets were resuspended and washed with $1 \mathrm{ml}$ PBS, briefly vortexed, then centrifuged at 9,000 $\times \mathrm{g}$ for 4 min and the supernatant pipetted off. The process was repeated three times before finally adding $50 \mu \mathrm{l}$ PBS to yield bacterial cell suspensions that were then stored at $-20{ }^{\circ} \mathrm{C}$ until use.

In addition, bark panels were collected from two bleed areas of $Q$. robur Tree 2 at the field site. Bark samples were surface sterilized for $1 \mathrm{~min}$ in $70 \%$ ethanol, $1 \mathrm{~min}$ in $0.5 \%$ sodium hypochlorite (Sigma), and thoroughly rinsed in sterile distilled water. Phloem tissue that spanned the healthy/lesion interface was plated onto PYGA bacterial culture medium (Denman et al., 2016). Emergent bacteria were streaked onto NA plates to obtain single colonies. These were resuspended in $100 \mu \mathrm{PBS}$ and subjected to PCR amplification of the 
gyrB fragment (Brady et al., 2008). BlastN analysis (Altschul et al., 1990) was applied to query sequences against GenBank to identify bacterial species.

\section{Results}

\subsection{TaqMan primer and probe design and specificity of the assay}

Multiple sequence alignments of gyrB sequences from Brenneria sp., Lonsdalea sp., and Rahnella sp. (Figure 1) indicated polymorphisms between closely related species in the gene regions to which probes and primers were designed (Figure 1). However, primers and probes had identical sequences to the species from which they were designed. Multiple sequence alignment of the $g y r B$ gene sequences from $B$. goodwinii were compared with closely related B. roseae subsp. americana and B. roseae subsp. roseae indicating that there is a single polymorphism between the gyrB sequence from B. roseae subsp. americana and the forward primer, while there are two mismatches between both B. roseae subspecies and the reverse primer. Similarly, the two B. roseae subspecies exhibit two base mismatches with the gyr $B$ gene probe designed to $B$. goodwinii. These differences were enough for the multiplex assay to identify B. goodwinii at an early $\mathrm{Cp}$ in the $\mathrm{qPCR}$, whilst related Brenneria sp. only amplified at Cps of greater than 35 cycles. We therefore only positively identified $B$. goodwinii if $\mathrm{Cp}$ values of less than 35 were obtained.

Primers and probes designed to G. quercinecans rpo were able to amplify and detect closely related Gibbsiella species: G. acetica, G. dentisursi, and G. greigii. Similarly, the qPCR TaqMan assay for $R$. victoriana was able to detect $R$. variigena (Table 1 ). No cross reaction between B. goodwinii, L. britannica, R. victoriana, and G. quercinecans was observed. Amplification was not observed in closely related species or non-target species 
isolated from plant lesions and cankers including Erwinia billingae, Klebsiella michiganensis, Lelliottia sp. nov., Ochrobactum sp., Panotea rodasii, Raoultella spp., and various Serratia species (Table S1).

\subsection{Sensitivity of multiplex TaqMan PCR}

Purified gyrB amplicons from B. goodwinii, L. britannica and $R$ victoriana and the rpoI amplicon from G. quercinecans were quantified, and serial dilutions were made for each of the products ranging from $10^{11}$ copies to $10^{2}$ copies. Plots of $\mathrm{Cp}$ versus $\log _{10}$ gene copy number indicated that reaction efficiencies of amplicons from all four bacteria were above $80 \%$ and $R^{2}>.99$ (Figure 2 ). The sensitivity of the multiplex TaqMan assay was determined using serial dilutions of AOD bacteria and the minimum number of bacterial cells detected were 14 for G. quercinecans, 76 for B. goodwinii, 75 for L. britannica, and 25 for $R$. victoriana (Table 3$)$.

\subsection{Multiplex PCR amplification from swab samples}

Bacterial suspensions obtained from processed swabs from $Q$. robur trees collected at a field site in south-east England (Figure 3) were assessed with the multiplex TaqMan assay for AOD-associated bacteria, and gene copy standards were included on the reaction plate in order to quantify the numbers of bacteria isolated from each swab sample. B. goodwinii and Gibbsiella sp. were detected in three of the four trees. B. goodwinii was present at higher levels in the exudates than Gibbsiella sp., and Tree 4 had the highest numbers of B. goodwinii $\left(2.7 \times 10^{7}\right)$ and Gibbsiella sp. $\left(2.36 \times 10^{3}\right)$ cells. Rahnella sp. was only present in Tree 2 (Figure 4). Although Tree 1 had a single dry stem bleed, no AOD bacteria were detected and the cause of the bleed was probably due to a wound and not further diagnosed. 
In order to validate the results obtained with the AOD multiplex TaqMan assay, two bark panels were taken from Tree 2 . A total of 29 bark pieces were extracted from two bark panels from Tree 2 and were plated onto PYGA from which bacteria were isolated from 19 bark pieces. BlastN analysis of the sequenced gyrB (Table 4) indicated that B. goodwinii (one isolate), G. quercinecans (seven isolates), and $R$. variigena (five isolates) were all present in necrotic tissue, confirming real-time PCR results from swab samples.

\section{Discussion}

Diagnosis of AOD in oak trees is based on the presence of $A$. biguttatus larval galleries in the inner bark, and often the presence of exit holes, stem bleeds, and occurrence of AODassociated bacteria in the necrotic tissue beneath the bleeds. Until recently, identification of AOD bacteria has relied heavily on destructive sampling of the inner bark tissue, bacterial isolation, strain purification, DNA extraction, PCR, sequencing, and BLAST identification. Here we present a multiplex TaqMan method for the rapid and simultaneous detection of four bacteria present in stem bleeds associated with AOD that can be applied to raw samples eliminating a culturing step, saving time and labour costs. The method can distinguish $B$. goodwinii from other Brenneria sp., and can detect Gibbsiella sp., Lonsdalea sp., and Rahnella sp. to genus level. Importantly, there was no cross detection of AOD bacterial species in the assay. Inclusion of gene copy number standards for each of the genes amplified from the four species enabled quantification of bacteria from the stem swab bleed sample. The multiplex TaqMan assay was effectively applied to identify and quantify bacteria in stem bleeds from oak trees showing decline symptoms in south-east England.

The multiplex TaqMan assay for AOD bacteria was effectively able to discriminate $B$. goodwinii from other Brenneria sp. at $\mathrm{Cp}$ values lower than 35 . This distinction is important 
as occasionally $B$. roseae subsp. roseae is also found in necrotic tissue associated with bleeding tree cankers. However, it is possible that this subspecies has a virulence gene repertoire similar to that of $B$. goodwinii and can perform the same necrotic function as $B$. goodwinii in bleeding stem cankers. This hypothesis is currently being tested through genome comparison studies to examine the virulence gene complement in both species (author's unpublished data). Gibbsiella spp. could only be detected to the genus level, but G. greigii has so far only been isolated from California black oak in the USA (Brady et al., 2014a), and G. dentisursi was isolated from the oral cavity of a bear in Japan and the intestine of a butterfly in Korea (Brady et al., 2015). Although Geider and co-workers unified all known Gibbsiella species in G. acetica (Geider et al., 2015), ongoing research in our laboratories indicates that this grouping is incorrect, and isolate BKI used in this study belongs to $G$. quercinecans (C. Brady, University of the West of England, UK, personal communication). Thus, as shown here, application of the TaqMan assay should only detect G. quercinecans on European oak trees. The assay could detect both $R$. variigena and $R$. victoriana in oak stem bleeds; both bacteria have previously been isolated from necrotic lesions on oak trees (Doonan et al., 2019).

The multiplex TaqMan protocol was applied to rapidly identify AOD-associated bacteria present on swab samples collected from oak stem bleeds at a field site in south-east England. Trees with prolific stem bleeds all contained both B. goodwinii and G. quercinecans. This was expected as B. goodwinii was highly abundant and dominated the AOD lesion microbiome in previous studies; G. quercinecans was consistently present in the AOD lesion microbiome (Broberg et al., 2018; Denman et al., 2018). Although the assay indicated that B. goodwinii was the most abundant bacteria in stem bleeds, only one isolate of this bacteria was obtained from bark isolations. B. goodwinii is facultatively anaerobic (Denman et al., 2012) and is outcompeted by other bacteria under aerobic growth conditions, 
thus yielding low numbers of isolates. Only bleeds from Tree 2 harboured Rahnella sp., but this genus is more ubiquitous than G. quercinecans, and has been shown to be associated with oak trees both with and without symptoms (Broberg et al., 2018).

Acute oak decline symptoms can develop rapidly, resulting in high levels of tree mortality (Denman et al., 2010). It is therefore necessary to implement management strategies to help curb the spread of the disease. Such strategies include surveying woodlands for AOD symptoms on Quercus sp., identification of disease-causing agents including AODassociated bacteria and A. biguttatus, and if necessary, felling diseased oaks and appropriate disposal of diseased tissue (Denman et al., 2010; Brown et al., 2016). As other pathogens such as Phytophthora sp. can cause stem bleeds on oak (Denman et al., 2019), it is necessary to ensure that bleeds are indeed associated with AOD bacteria. The multiplex real-time PCR assay described in this paper provides a rapid diagnostic tool to identify bacteria, which can be applied to monitoring programmes to minimize the spread of the disease to other trees.

In 2019 alone, Forest Research processed 208 swab samples from oak trees sent in by the public and scientists both in the UK and in Europe. Presence of AOD bacteria in combination with photographic evidence of tree decline, bark cracking and, if present, $A$. biguttatus exit holes are used to diagnose AOD. If photographic evidence strongly suggests that an oak tree has AOD, but swab samples are negative for presence of associated bacteria, we recommend that a further swab is taken when the bleed is more active (e.g., spring or early summer) or in some cases we apply a selective enrichment culturing procedure using eosin methylene-blue (EMB) culture media (Moradi-Amirabad et al., 2019). An important application of the rapid diagnostic assay would be to detect seasonal changes in AOD bacterial dynamics as well as differences in AOD bacterial composition in lesions as they progress. 
Future research will focus on improving the specificity of the multiplex TaqMan assay for specific detection of G. quercinecans. This could be achieved by designing primers and a fluorescent probe to a different gene which is conserved between G. quercinecans isolates but differs between Gibbsiella species. Ongoing sequencing projects to compare different Gibbsiella sp. genomes (author's unpublished data) will greatly assist in the selection of such a gene region. An alternative approach in the short term could be to include locked nucleic acids (LNA) bases at nucleotide positions that distinguish G. quercinecans from other Gibbsiella species. LNA bases are modified RNA analogues in which an oxymethylene bridge locks the ribose ring in the ideal conformation for specific binding to the complementary base. This increases hybridization stability and ensures differentiation between closely related sequences down to as little as one nucleotide difference (Kauppinen et al., 2005; Lumia et al., 2018). Furthermore, probes could be designed to include a minor groove binder (MGB) at their $3^{\prime}$ end. This would increase the probe-target duplex stability and enable the use of shorter target specific probes (Roussel et al., 2005). Roussel and coworkers (2005) designed probes with MGBs to detect fruit tree viruses that have high genome variability and it was thus necessary to target a small number of conserved nucleotides shared among different isolates.

In conclusion, we have presented a rapid TaqMan PCR method to simultaneously detect bacteria associated with tree stem bleeds. Moreover, the protocol presented here is nondestructive and allows for detection of bacteria directly from stem bleeds without the need for removal of inner bark panels from high commodity trees. This will greatly assist diagnostics and management of AOD in woodland areas.

\section{Acknowledgements}


The authors would like to thank DEFRA and the Forestry Commission for funding this research. We acknowledge Dr Carrie Brady from the University of the West of England for her helpful discussions and insights into the taxonomy of Gibbsiella and Lonsdalea genera. The authors have no conflicts of interest to declare.

\section{Data availability statement}

The data that support the findings of this study are available from the corresponding author upon reasonable request.

\section{References}

Altschul SF, Gish W, Miller W, Myers EW and Lipman DJ (1990) Basic local alignment search tool. Journal of Molecular Biology 215, 403-410.

Brady C, Cleenwerck I, Venter SN, Vancanneyt M, Swings J and Coutinho TA (2008) Phylogeny and identification of Pantoea species associated with plants, humans and the natural environment based on multilocus sequence analysis (MLSA). Systematic and Applied Microbiology 31, 447-460.

Brady C, Hunter G, Kirk S, Arnold D and Denman S (2014a) Gibbsiella greigii sp. nov., a novel species associated with oak decline in the USA. Systematic and Applied Microbiology 37, 417-422.

Brady C, Hunter G, Kirk S, Arnold D and Denman S (2014b) Rahnella victoriana sp. nov., Rahnella bruchi sp. nov., Rahnella woolbedingensis sp. nov., classification of Rahnella genomospecies 2 and 3 as Rahnella variigena sp. nov. and Rahnella inusitata sp. nov., 
respectively and emended description of the genus Rahnella. Systematic and Applied Microbiology 37, 545-552.

Brady C, Irisawa T, Iino T, Ohkuma M, Arnold D and Denman S (2015) Gibbsiella papilionis Kim et al. 2013 is a later heterotypic synonym of Gibbsiella dentisursi Saito et al. 2013. International Journal of Systematic and Evolutionary Microbiology 65, 4788-4791.

Brady C, Allainguillaume J, Denman S and Arnold D (2016) Rapid identification of bacteria associated with Acute Oak Decline by high-resolution melt analysis. Letters in Applied Microbiology 63, 89-95.

Brady C, Arnold D, McDonald J and Denman S (2017) Taxonomy and identification of bacteria associated with acute oak decline. World Journal of Microbiology and Biotechnology 33, 143.

Broberg M, Doonan J, Mundt F, Denman S and McDonald JE (2018) Integrated multi-omic analysis of host-microbiota interactions in acute oak decline. Microbiome 6, 21.

Brown N, Jeger M, Kirk S, Xu X and Denman S (2016) Spatial and temporal patterns in symptom expression within eight woodlands affected by Acute Oak Decline. Forest Ecology and Management 360, 97-109.

Brown N, Jeger M, Kirk S, Williams D, Xu X, Pautasso M et al. (2017) Acute Oak Decline and Agrilus biguttatus: the co-occurrence of stem bleeding and D-shaped emergence holes in Great Britain. Forests 8, 87.

Brown N, Vanguelova E, Parnell S, Broadmeadow S and Denman S (2018) Predisposition of forests to biotic disturbance: Predicting the distribution of Acute Oak Decline using 
environmental factors. Forest Ecology and Management 407, 145-154.

Chandelier A, Massot M, Fabreguettes O, Gischer F, Teng F and Robin C (2019) Early detection of Cryphonectria parasitica by real-time PCR. European Journal of Plant Pathology 153, 29-46.

Denman S and Webber JF (2009) Oak declines - new definitions and new episodes in Britain. Quarterly Journal of Forestry 103, 285-290.

Denman S, Kirk S and Webber J (2010) Managing Acute Oak Decline. Forestry Commission Note FCPN015. Farnham: Forestry Commission.

Denman S, Brady C, Kirk S, Cleenwerck I, Venter S, Coutinho T et al. (2012) Brenneria goodwinii sp. nov., associated with acute oak decline in the UK. International Journal of Systematic and Evolutionary Microbiology 62, 2451-2456.

Denman S, Brown N, Kirk S, Jeger M and Webber J (2014) A description of the symptoms of Acute Oak Decline in Britain and a comparative review on causes of similar disorders on oak in Europe. Forestry 87, 535-551.

Denman S, Plummer S, Kirk S, Peace A and McDonald JE (2016) Isolation studies reveal a shift in the cultivable microbiome of oak affected with Acute Oak Decline. Systematic and Applied Microbiology 39, 484-490.

Denman S, Doonan J, Ransom-Jones E, Broberg M, Plummer S, Kirk S et al. (2018)

Microbiome and infectivity studies reveal complex polyspecies tree disease in Acute Oak Decline. The ISME Journal 12, 386-399.

Denman S, Crampton B, Kajamuhan A and McDonald J (2019) Pathogen threats to native oaks in the UK. In: Quine, C., Atkinson, N., Denman, S., Desprez-Loustau, L., Jackson, 
R. and Kirby, K. (Eds.) Action Oak Knowledge Review: An Assessment of the Current Evidence on Oak Health in the UK, Identification of Evidence Gaps and Prioritisation of Research Needs. Haslemere, UK: Action Oak, pp. 65-94.

Doonan J, Denman S, Pachebat JA and McDonald JE (2019) Genomic analysis of bacteria in the Acute Oak Decline pathobiome. Microbial Genomics 5, e000240.

Enora D, Martial B, Marie-Agnès J and Sophie C (2019) Novel tetraplex qPCR assays for simultaneous detection and identification of Xylella fastidiosa subspecies in plant tissues. bioRxiv, 699371. [Preprint].

Fonseca NP, Felestrino ÉB, Caneschi WL, Sanchez, AB, Cordeiro IF, Lemes CGC et al. (2019) Detection and identification of Xanthomonas pathotypes associated with citrus diseases using comparative genomics and multiplex PCR. PeerJ 7, e7676.

Geider K, Gernold M, Jock S, Wensing A. Völksch B, Gross J et al. (2015) Unifying bacteria from decaying wood with various ubiquitous Gibbsiella species as G. acetica sp. nov. based on nucleotide sequence similarities and their acetic acid secretion. Microbiological Research 181, 93-104.

González AJ and Ciordia M (2020) Brenneria goodwinii and Gibbsiella quercinecans isolated from weeping cankers on Quercus robur L. in Spain. European Journal of Plant Pathology 156, 965-969.

Ibekwe AM, Watt PM, Grieve CM, Sharma VK and Lyons SR (2002) Multiplex fluorogenic real-time PCR for detection and quantification of Escherichia coli $\mathrm{O} 157: \mathrm{H} 7$ in dairy wastewater wetlands. Applied and Environmental Microbiology 68, 4853-4862.

Kaczmarek M, Mullett MS, McDonald JE and Denman S (2017) Multilocus sequence typing 
provides insights into the population structure and evolutionary potential of Brenneria goodwinii, associated with acute oak decline. PLoS ONE 12, e0178390.

Kauppinen S, Vester B and Wengel J (2005) Locked nucleic acid (LNA): High affinity targeting of RNA for diagnostics and therapeutics. Drug Discovery Today: Technologies 2, 287-290.

Koressaar T and Remm M (2007) Enhancements and modifications of primer design program Primer3. Bioinformatics 23, 1289-1291.

Li Y, Xue H, Guo L-M, Koltay A, Palacio-Bielsa A, Chang J et al. (2017) Elevation of three subspecies of Lonsdalea quercina to species level: Lonsdalea britannica sp. nov., Lonsdalea iberica sp. nov. and Lonsdalea populi sp. nov. International Journal of Systematic and Evolutionary Microbiology 67, 4680-4684.

Liu J, Gratz J, Amour C, Kibiki G, Becker S, Janaki L et al. (2013) A laboratory-developed TaqMan array card for simultaneous detection of 19 enteropathogens. Journal of Clinical Microbiology 51, 472-480.

Lumia V, Modesti V, Brunetti A, Wilkinson CL, Di Lernia G, Harrington TC et al. (2018) Real-Time PCR for Ceratocystis platani detection: in-depth validation to assess the diagnostic potential and include additional technical options. iForest - Biogeosciences and Forestry 11, 499-509.

Moradi-Amirabad Y, Rahimian H, Babaeizad V and Denman S (2019) Brenneria spp. and Rahnella victoriana associated with acute oak decline symptoms on oak and hornbeam in Iran. Forest Pathology 49, e12535.

Pfaffl MW (2004) Quantification strategies in real-time PCR In: Bustin SA (Ed.) The Real- 
Time PCR Encyclopedia A-Z of Quantitative PCR. La Jolla, CA: International University Line, pp. 87-112.

Roussel S, Kummert J, Salmon M, Dutrecq O and Jijakli MH (2005) Development of RTPCR assays using fluorogenic-3' minor groove binder DNA probes for detection of fruit tree viruses. EPPO Bulletin 35, 105-108.

Sapp M, Lewis E, Moss S, Barrett B, Kirk S, Elphinstone JG et al. (2016) Metabarcoding of bacteria associated with the Acute Oak Decline syndrome in England. Forests 7, 95.

Schaad NW and Frederick RD (2002) Real-time PCR and its application for rapid plant disease diagnostics. Canadian Journal of Plant Pathology 24, 250-258.

Smith JM, Feil EJ and Smith NH (2000) Population structure and evolutionary dynamics of pathogenic bacteria. BioEssays 22, 1115-1122.

Untergasser A, Cutcutache I, Koressaar T, Ye J, Faircloth BC, Remm M et al. (2012) Primer3 - new capabilities and interfaces. Nucleic Acids Research 40, e115-e.

Vinatzer BA, Monteil CL and Clarke CR (2014) Harnessing population genomics to understand how bacterial pathogens emerge, adapt to crop hosts, and disseminate. Annual Review of Phytopathology 52, 19-43.

Weller SA, Elphinstone JG, Smith NC and Stead DE (2000) Detection of Ralstonia solanacearum from potato tissue by post-enrichment TaqMan PCR. EPPO Bulletin 30, $381-383$.

Supporting Information 
Additional Supporting Information may be found in the online version of this article at the publisher's web-site.

Table S1 Non-target bacteria tested for nonspecific detection with acute oak declineassociated bacteria primers and probes.

Table S2 GenBank accession numbers of sequences used to design primers and probes for Brenneria goodwinii, Gibbsiella quercinecans, Lonsdalea britannica, and Rahnella victoriana.

Figure legends

Figure 1 Multiple alignments of gyraseB $(g y r B)$ gene fragments for detection of (a) Brenneria goodwinii, (b) Lonsdalea britannica, and (c) Rahnella victoriana and the rpo fragment for detection of (d) Gibbsiella quercinecans. The binding sites of respective primers and probes are indicated on the alignments. Genes for bacteria associated with acute oak decline were set as the reference and were aligned to homologs of closely related species within a genus to detect polymorphisms between species and determine optimal primer/probe positions. Bg, Brenneria goodwinii; Brr, Brenneria roseae subsp. roseae; Bra, Brenneria roseae subsp. americana; Bn, Brenneria nigrifluens; Brub, Brenneria rubrifaciens; Bs, Brenneria salicis; Ba, Brenneria alni; Lb, Lonsdalea britannica; Lq, Lonsdalea quercina; Li, Lonsdalea iberica; Rvic, Rahnella victoriana; Raq, Rahnella aquatilis; Rvar, Rahnella variigena; Rinus, Rahnella inusitata; Rb, Rahnella bruchi; Rwool, Rahnella woolbedingensis; Gq, Gibbsiella quercinecans. Isolate numbers are indicated in brackets after species abbreviations. 
Figure 2 Linear relationship between crossing point (Cp) and gene copy number (log transformed) for Brenneria goodwinii $(\bullet)$, Gibbsiella quercinecans $(\triangle)$, Rahnella victoriana $(+)$, and Lonsdalea britannica $(\times)$. Linear regression curves were calculated for each species and reaction efficiencies for each bacterial species was determined from the slope of the regression curve. Regression curves were as follows: B. goodwinii, $y=-3.8037 x+43.087$; G. quercinecans, $y=-3.5354 x+44.567 ; R$. victoriana, $y=-3.6141 x+44.42$; and $L$. britannica, $y=-3.6268 x+46.745$.

Figure 3 Decline symptoms on Quercus robur trees in a site in south-east England. (a) Tree 1 displaying dieback of upper branches. (b) Tree 2 and (c) Tree 3 with numerous bleeds along the length of the stem. (d) Tree 4 with a bleed at the base of the stem.

Figure 4 Detection and quantification of acute oak decline-associated bacteria on oak trees at a field site in south-east England. Tree 1 had a dry stem bleed and no acute oak declineassociated bacteria were detected. 
A.

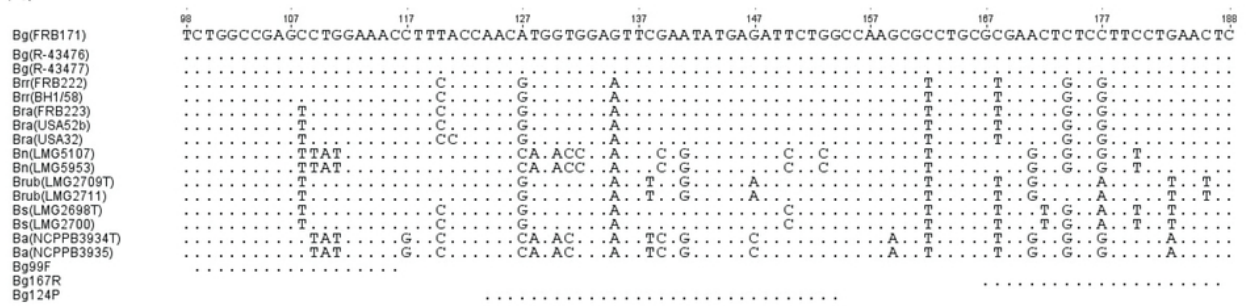

B.

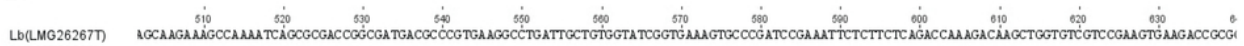

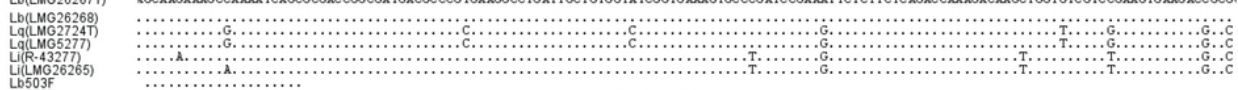

C.

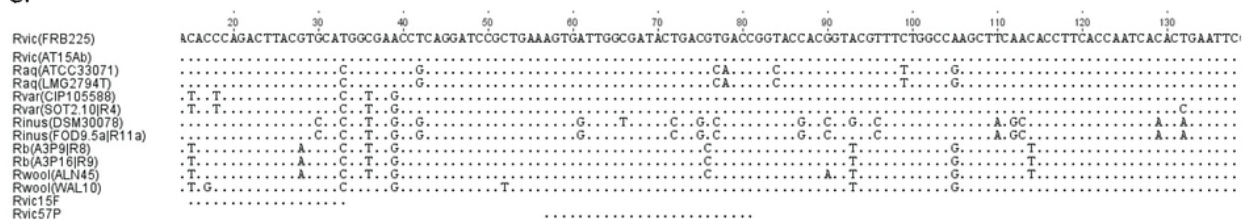

D.

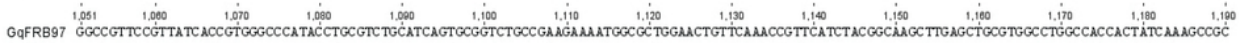
$G q 284 F$
$G G 342 P$
$G q 418 R$

$167 \times 123 \mathrm{~mm}(150 \times 150 \mathrm{DPI})$ 


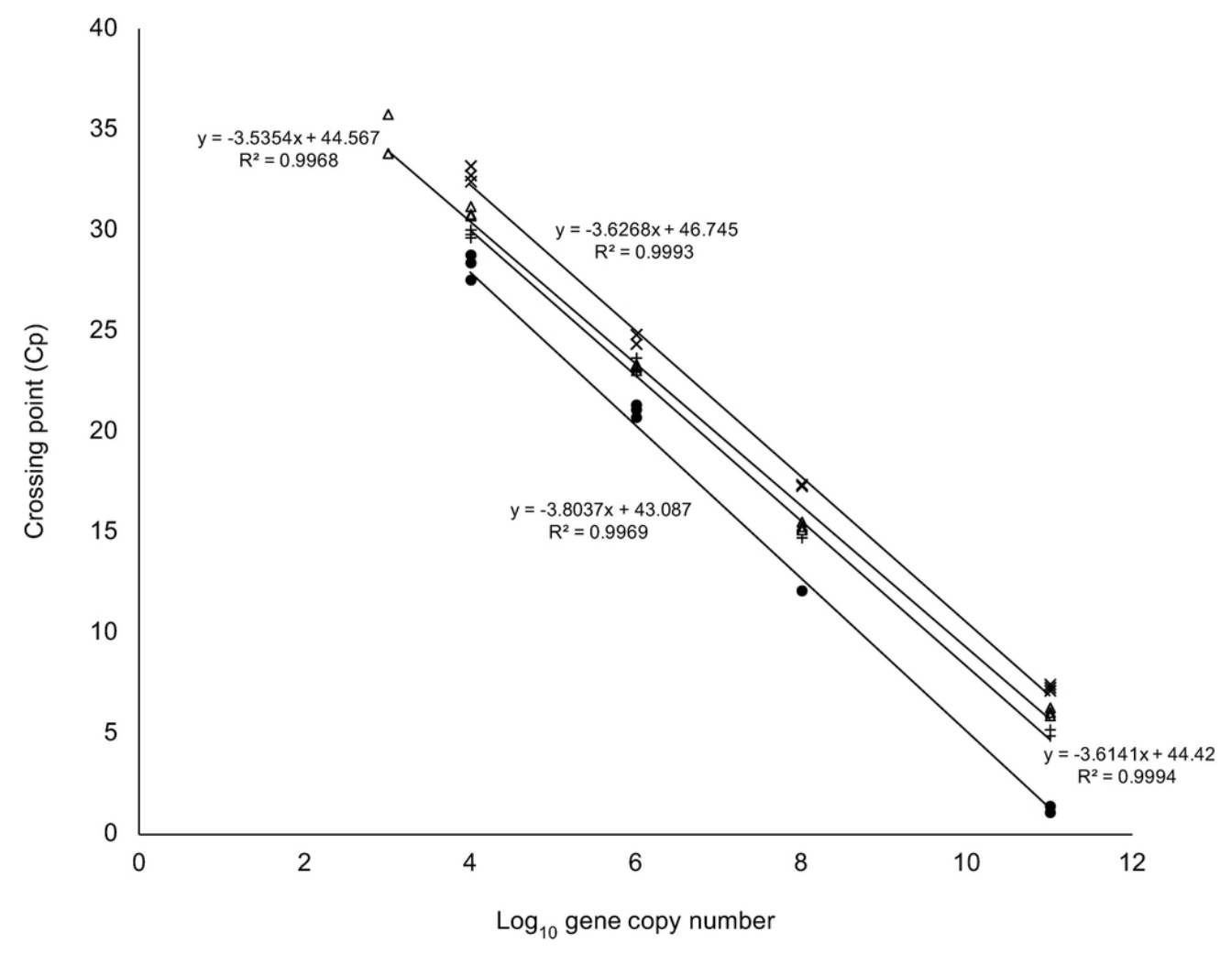

$173 \times 135 \mathrm{~mm}(150 \times 150 \mathrm{DPI})$ 

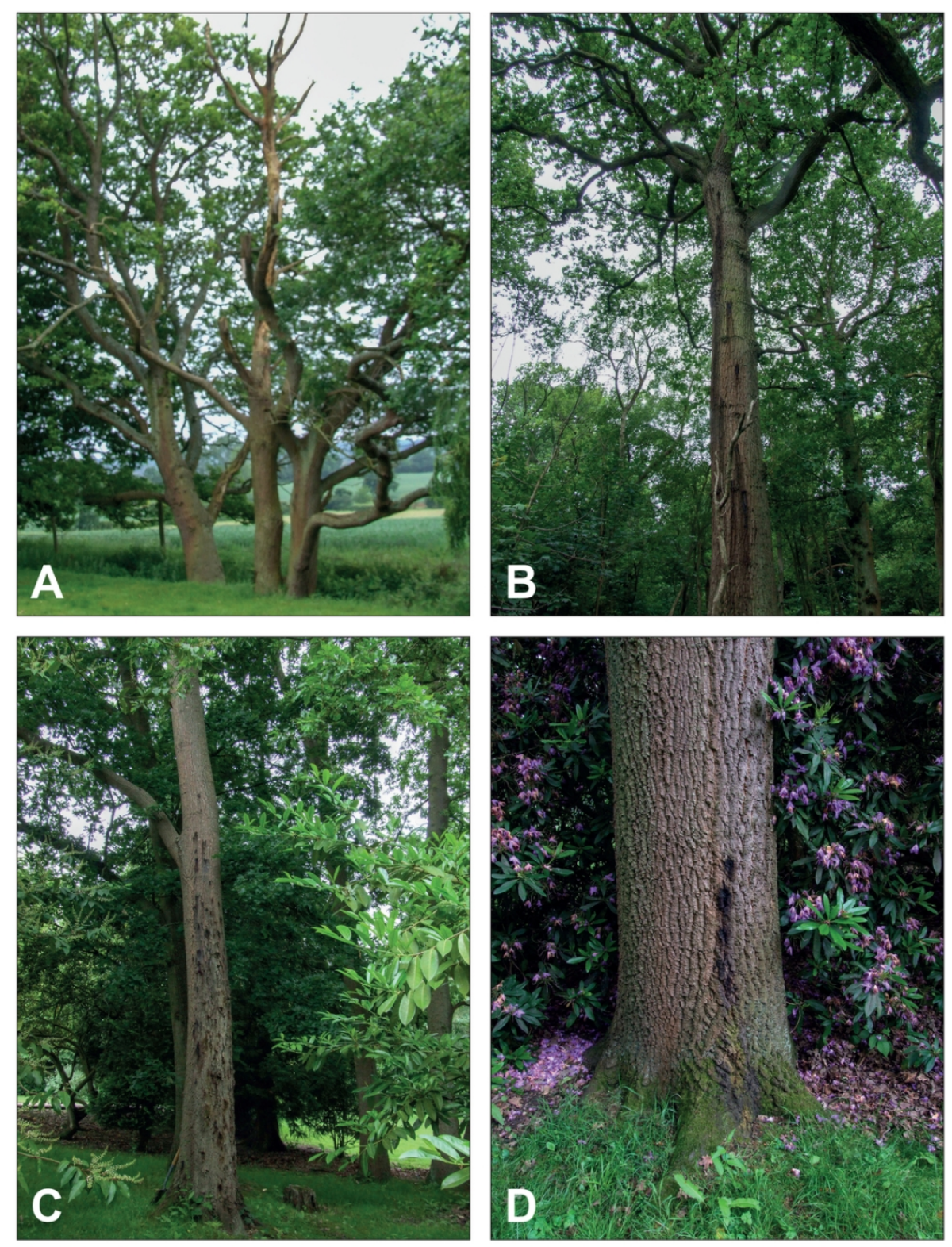

$191 \times 246 \mathrm{~mm}(150 \times 150 \mathrm{DPI})$ 


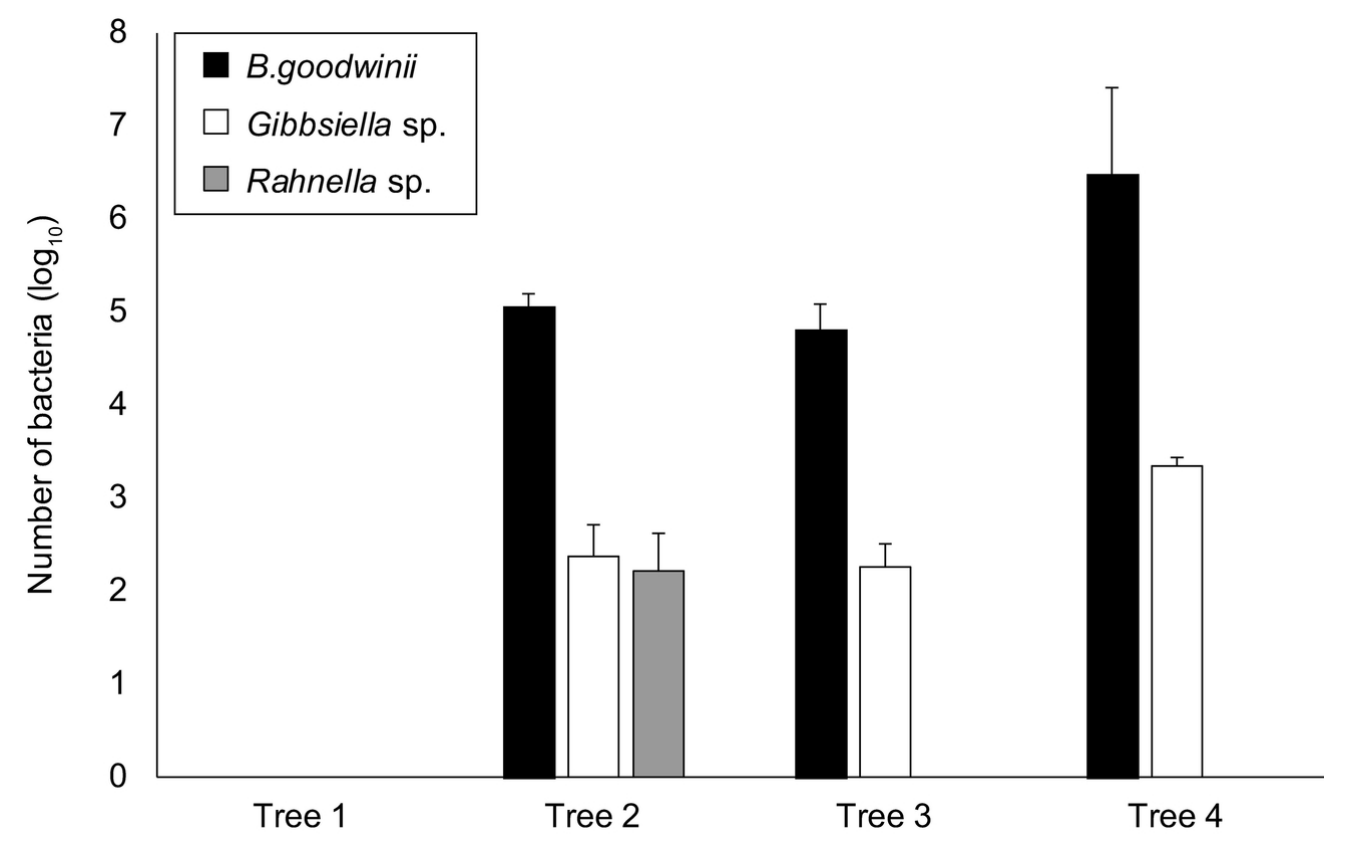

$219 \times 138 \mathrm{~mm}(150 \times 150 \mathrm{DPI})$ 
Table 1 Bacterial reference strains used in this study and their associated real-time PCR detection result

\begin{tabular}{|c|c|c|c|c|c|c|}
\hline \multirow[b]{2}{*}{ Bacterial species } & \multirow{2}{*}{$\begin{array}{l}\text { Isolate } \\
\text { number }\end{array}$} & \multirow[b]{2}{*}{ Host association } & \multicolumn{4}{|c|}{ PCR detection ${ }^{a}$} \\
\hline & & & Bg & Lb & Rvic & Gq \\
\hline Brenneria alni & NCPPB934 & Alnus sp. & - & - & - & - \\
\hline \multirow[t]{3}{*}{ Brenneria goodwinii } & FRB171 & Quercus robur & + & - & - & - \\
\hline & FRB $141^{\mathrm{T}}$ & Q. robur & + & - & - & - \\
\hline & FRB186 & Q. robur & + & - & - & - \\
\hline Brenneria roseae ssp. & $\mathrm{FRB} 222^{\mathrm{T}}$ & Q. robur & - & - & - & - \\
\hline \multirow[t]{5}{*}{ roseae } & $\mathrm{BH} 1 / 40 \mathrm{~b}$ & Q. robur & - & - & - & - \\
\hline & $\mathrm{BH} 1 / 43 \mathrm{c}$ & Q. robur & - & - & - & - \\
\hline & $\mathrm{BH} 1 / 43 \mathrm{~d}$ & Q. robur & - & - & - & - \\
\hline & $\mathrm{BH} 1 / 58$ & Q. robur & - & - & - & - \\
\hline & $\mathrm{BH} 1 / 82 \mathrm{~b}$ & Q. robur & - & - & - & - \\
\hline \multirow[t]{3}{*}{ B. roseae ssp. americana } & FRB223 & Quercus kelloggi & - & - & - & - \\
\hline & USA32 & Q. kelloggi & - & - & - & - \\
\hline & USA $52 b$ & Q. kelloggi & - & - & - & - \\
\hline Brenneria rubrifaciens & NCPPB2020 & Jugulans regia & - & - & - & - \\
\hline Brenneria salicis & NCPPB $447^{\mathrm{T}}$ & Salix sp. & - & - & - & - \\
\hline Gibbsiella acetica & BK1 & $\begin{array}{l}\text { Necrotic apple } \\
\text { wood }\end{array}$ & - & - & - & + \\
\hline \multirow[t]{3}{*}{ Gibbsiella dentisursi } & DSM23818 & Oral cavity of a & - & - & - & + \\
\hline & & bear & & & & \\
\hline & LEN33 & Butterfly intestine & - & - & - & + \\
\hline Gibbsiella greigii & FRB224T & Q. kelloggi & - & - & - & + \\
\hline \multirow[t]{3}{*}{ Gibbsiella quercinecans } & FRB97 & Q. robur & - & - & - & + \\
\hline & FRB24 & Q. robur & - & - & - & + \\
\hline & $\mathrm{BH} 1 / 19$ & Q. robur & - & - & - & + \\
\hline \multirow[t]{2}{*}{ Lonsdalea britannica } & FRB18 & Q. robur & - & + & - & - \\
\hline & DUD5 & Q. robur & - & + & - & - \\
\hline Rahnella bruchi & FRB226T & Agrilus biguttatus & - & - & - & - \\
\hline Rahnella inusitata & B1 & Unknown & - & - & - & - \\
\hline Rahnella variiega & CIP105588 & Human burn & - & - & + & - \\
\hline
\end{tabular}




$\begin{array}{llllll}\text { Rahnella victoriana } & \text { FRB141a } & \text { Q. robur } & - & - \\ \text { Rahnella woolbedingensis } & \text { FRB227 } & \text { Alnus glutinosa } & - & - & -\end{array}$

Note. +, positive detection; -, negative detection.

aProbe for: Bg, Brenneria goodwinii; Lb, Lonsdalea britannica; Rvic, Rahnella victoriana; Gq, Gibbsiella quercinecans. 
Table 2 Primer and TaqMan probe sequences for multiplex quantitative PCR detection of acute oak decline-associated bacteria

\begin{tabular}{|c|c|c|c|c|}
\hline Species & Gene & Primer $^{\mathrm{a}}$ & Sequence $\left(5^{\prime}-3^{\prime}\right)$ & $\begin{array}{l}\text { Product } \\
\text { size (bp) }\end{array}$ \\
\hline $\begin{array}{l}\text { Brenneria } \\
\text { goodwinii }\end{array}$ & gyrB & $\begin{array}{l}\text { Bg99F } \\
\text { Bg179R } \\
\text { Bg124P }\end{array}$ & $\begin{array}{l}\text { CTGGCCGAGCCTGGAAAC } \\
\text { AGTTCAGGAAGGAGAGTTCGC } \\
\text { FAM- } \\
\text { CCAGAATCTCATATTCGAACTCCACCA } \\
\text { TGTT-BHQ1 }\end{array}$ & 88 \\
\hline $\begin{array}{l}\text { Gibbsiella } \\
\text { quercinecan } \\
s\end{array}$ & rрo & $\begin{array}{l}\text { Gq284F } \\
\text { Gq418R } \\
\text { Gq342P }\end{array}$ & $\begin{array}{l}\text { GGCTTTGATAGTGGTGGCC } \\
\text { CGTTCCGTTATCACCGTGG } \\
\text { Cy5- } \\
\text { AACAGTTCCAGCGCCATTTTCTTCG- } \\
\text { BHQ3 }\end{array}$ & 134 \\
\hline $\begin{array}{l}\text { Lonsdalea } \\
\text { britannica }\end{array}$ & gyrB & $\begin{array}{l}\text { Lq503F } \\
\text { Lq634R } \\
\text { Lq555P }\end{array}$ & $\begin{array}{l}\text { GCAAGAAAGCCAAAATCAGC } \\
\text { TCTTCACTTCGGACGACACC } \\
\text { JOE- } \\
\text { TGCTGTGGTATCGGTGAAAGTGCCC- } \\
\text { BHQ1 }\end{array}$ & 131 \\
\hline $\begin{array}{l}\text { Rahnella } \\
\text { victoriana }\end{array}$ & gyrB & $\begin{array}{l}\text { Rv15F } \\
\text { Rv134R } \\
\text { Rv57P }\end{array}$ & $\begin{array}{l}\text { CACCCAGACTTACGTGCAT } \\
\text { TCAGTGTGATTGGTGAAGGT } \\
\text { ROX- } \\
\text { AGTGATTGGCGATACTGACGTGACC- } \\
\text { BHQ2 }\end{array}$ & 119 \\
\hline
\end{tabular}

${ }_{\mathrm{a}}^{\mathrm{F}}$, forward; $\mathrm{R}$, reverse; $\mathrm{P}$, probe. 
Table 3 Assessment of the sensitivity of the acute oak decline (AOD) TaqMan assay to detect bacterial species

\begin{tabular}{|c|c|c|c|c|}
\hline $\begin{array}{l}\text { AOD-associated } \\
\text { bacterial species }\end{array}$ & $\begin{array}{l}\text { Dilution } \\
\text { factor }\end{array}$ & $\begin{array}{l}\text { Colony } \\
\text { count }^{\mathrm{a}}\end{array}$ & $\begin{array}{l}\text { Equivalent } \\
\text { cfu/ml }\end{array}$ & $\begin{array}{l}\text { TaqMan Cq } \\
\text { value }^{\mathrm{a}}\end{array}$ \\
\hline \multirow[t]{5}{*}{ Brenneria goodwinii } & $10^{-1}$ & TNTC & - & $16.07 \pm 0.57$ \\
\hline & $10^{-2}$ & TNTC & - & $23.97 \pm 1.82$ \\
\hline & $10^{-3}$ & $2203 \pm 48$ & $1.1 \times 10^{6}$ & $26.65 \pm 1.02$ \\
\hline & $10^{-4}$ & $417 \pm 72$ & $2.1 \times 10^{5}$ & $28.70 \pm 1.87$ \\
\hline & $10^{-5}$ & $76 \pm 2$ & $3.8 \times 10^{4}$ & $34.13 \pm 0.84$ \\
\hline \multirow[t]{5}{*}{ Gibbsiella quercinecans } & $10^{-1}$ & TNTC & - & $18.93 \pm 0.14$ \\
\hline & $10^{-2}$ & TNTC & - & $24.49 \pm 0.08$ \\
\hline & $10^{-3}$ & $1647 \pm 97$ & $8.2 \times 10^{5}$ & $27.67 \pm 0.03$ \\
\hline & $10^{-4}$ & $263 \pm 34$ & $1.3 \times 10^{5}$ & $31.36 \pm 0.10$ \\
\hline & $10^{-5}$ & $14 \pm 4$ & $7.0 \times 10^{3}$ & $35.72 \pm 0.28$ \\
\hline \multirow[t]{5}{*}{ Lonsdalea britannica } & $10^{-1}$ & TNTC & - & $21.47 \pm 0.48$ \\
\hline & $10^{-2}$ & TNTC & - & $25.48 \pm 0.18$ \\
\hline & $10^{-3}$ & $2107 \pm 257$ & $1.0 \times 10^{6}$ & $28.83 \pm 0.18$ \\
\hline & $10^{-4}$ & $557 \pm 66$ & $2.8 \times 10^{5}$ & $31.93 \pm 0.01$ \\
\hline & $10^{-5}$ & $75 \pm 11$ & $3.8 \times 10^{4}$ & $35.68 \pm 0.02$ \\
\hline \multirow[t]{5}{*}{ Rahnella victoriana } & $10^{-1}$ & TNTC & & $25.47 \pm 1.00$ \\
\hline & $10^{-2}$ & TNTC & & $28.84 \pm 0.03$ \\
\hline & $10^{-3}$ & $948 \pm 128$ & $4.7 \times 10^{5}$ & $31.51 \pm 0.15$ \\
\hline & $10^{-4}$ & $80 \pm 14$ & $4.0 \times 10^{4}$ & $35.13 \pm 0.83$ \\
\hline & $10^{-5}$ & $25 \pm 2$ & $1.2 \times 10^{3}$ & $36.85 \pm 1.29$ \\
\hline
\end{tabular}

Note. AOD-associated bacteria were grown, diluted, and plated at a volume equivalent to the volume added to the TaqMan assay. Colony count is the number of bacteria added to TaqMan assay. Counts were performed and compared with Cq values obtained in TaqMan PCRs for each of the bacterial species. TNTC, too numerous to count.

aEach sample consisted of three replicates. Reported values represent the average of the three replicates. 
Table 4 Bacteria isolated from lesions beneath stem bleeds of Quercus robur Tree 2 at a site in south-east England

\begin{tabular}{lll}
\hline Top BlastN hit & No. of isolates & Accession no. \\
\hline Brenneria goodwinii FR141 & 1 & CP014137.1 \\
Gibbsiella quercinecans FRB97 & 7 & CP014136.1 \\
Rahnella variigena & 5 & FJ268864.1
\end{tabular}

Note. Bacteria were identified by sequencing the gyrase $B$ gene and subsequent BlastN analysis ( $>99 \%$ query coverage; $>98 \%$ maximum identity). 